\title{
DEGRADASI LAHAN PADA BERBAGAI TANAMAN PERKEBUNAN DI KABUPATEN DHARMASRAYA SUMATERA BARAT
}

\author{
Syafrimen Yasin*), Herviyanti, D avid \\ Soil Science Department Agriculture College, Andalas University \\ Email: syafrimen_y@telkom.net
}

\begin{abstract}
A reseach about determination land degradation on several plantation ecosystems in Dharmasraya Regency, West Sumatra. This research was aimed to study types of perennial crops (trees) which contributes to alleviate land degradation. The work was conducted in Sungai Rumbai Dystrict, Dharmasraya regency and in Soil Science Laboratory, Agriculture Faculty Andalas University. Soil samplings were taken at Ultisols having 0-8\% slope (flateundulating). Land use type being considered was original forest, oil palm, rubber, coffee, and cocoa plantation. Composite soil samples were taken for four replications on 1-20 cm depth. At each sampling site was accompanied by five drilling soils. Then, four undisturbed soil was also sampled at the same depth with disturbed soil samples for determining soil bulk density values. The data collected were analyzed statistically by using analyses of variance, and then continued by using Least Significant Difference (LSD) at 5\% level. The result showed that rubber and cacao plantation contributed to better soil ecology value than oil palm and coffee land use. It could be proved from organic carbon (OC) and bulk density (BV) of the soils which were alsmost the same as those from forest land use.
\end{abstract}

Key Words: Land degradation, plantation crops

\section{PENDAHULUAN}

Di Sumatera Barat, pembukaan hutan besar-besaran terjadi antara tahun 1970 dan 1980 terutama di Kabupaten Dharmasraya, baik untuk peruntukan transmigrasi (lahan pekarangan, pangan, dan perkebunan) maupun untuk dijadikan perkebunan dengan berbagai jenis tanaman industri (karet, sawit, coklat, dll). Dengan telah terjadinya perubahan fungsi hutan ke berbagai penggunaan tersebut, tentu juga akan terjadi perbedaan dalam penurunan tingkat kesuburan tanah (degradasi lahan).

Ekosistim hutan merupakan ekosistim yang paling stabil dan sustainable. Hal ini disebabkan fungsinya yang dapat mensuplai hara sendiri melalui pengembalian bahan organik, mencegah terjadinya kehilangan hara melalui erosi dan pencucian, yang pada akhirnya akan menyebabkan laju input hara yang masuk ke sistim hutan tersebut akan sebanding dengan jumlah yang keluar dari sistim. Ekosistim hutan alami khususnya di daerah tropika diyakini merupakan ekosistim yang mempunyai siklus tertutup, dan merupakan suatu bentuk ekosistim yang berkelanjutan atau sustainable. Oleh karenanya ekosistim hutan alami sering dijadikan sebagai pembanding untuk menilai perubahan ke bentuk ekosistim lain.

Lerson dan Pierce (1991) menyatakan bahwa bahan organik tanah dapat dijadikan sebagai salah satu indeks dalam menentukan kualitas tanah dan sustainability. Bahan organik tanah sangat nyata mempengaruhi berbagai parameter tanah. Bahan organik tanah secara simultan juga merupakan sumber hara tanaman, secara fisika dan kimia akan memfasilitasi terbentuknya agregat dan struktur tanah, meningkatkan kandungan air tanah, sumber energi bagi biota tanah, dan selanjutnya akan berpengaruh terhadap proses biologi di dalam tanah.

Kandungan bahan organik tanah sangat ditentukan oleh keseimbangan antara faktor-faktor yang mempengaruhi pembentukannya dan faktor yang mempengaruhi proses pelapukannya. Faktor pembentuk meliputi jumlah dan kualitas dari sumber bahan organik, sedangkan faktor 
pelapukan ditentukan oleh kondisi yang mempengaruhi kecepatan oksidasi dari bahan organik tersebut. Pada daerah tropik umumnya perubahan dari ekosistim hutan ke lahan pertanian akan menurunkan kandungan bahan organik tanah ke tingkat keseimbangan yang rendah (Woomer dan Ingram, 1990; Guggenberger et al., 1994; 1995). Jumlah kehilangan bahan organik tanah tersebut bisa mencapai 20 sampai 50 $\%$.

Terjadinya penurunan kandung-an bahan organik menurut Woomer dan Ingram (1990) disebabkan oleh beberapa aspek, antara lain faktor erosi yang akan menghanyutkan bahan organik dan tanah lapisan atas yang kaya bahan organik. Namun demikian perubahan bahan organik tanah pada tanah yang tidak tererosi sangat dipengaruhi oleh kondisi fisika, kimia, dan biologi tanah. Menurut Nye dan Greenland (1960) dan Sanchez (1976) disamping jumlah penambahan bahan organik, kelembaban dan temperatur juga berperan penting dalam menentukan tingkat bahan organik tanah. Oleh karena itu perubahan kondisi tanah dengan berbagai manipulasi praktek pertanian seperti pengolahan tanah, pemupukan dan pengapuran akan dapat meningkatkan kandungan bahan organik tanah ke level tertentu, karena bahan organik tanah merupakan bahan yang dapat diperbaharui.

Yasin (2004) telah melakukan penelitian tentang penggunaan berbagai lahan di Kabupaten Dharmasraya. Dari hasil penelitian tersebut disimpulkan bahwa penggunaan lahan karet memiliki nilai ekonomi yang lebih tinggi dibandingkan jenis tanaman lain, seperti sawit, tegalan, dan kebun campuran. Namun demikian, bagaimana perbandingannya dengan jenis tanaman perkebunan lainnya belum banyak dilaporkan. Untuk itu, dirasa perlu melakukan penelitian degradasi lahan pada berbagai perkebunan.

Penelitian ini bertujuan untuk melihat degradasi lahan pada berbagai jenis tanaman perkebunan.

\section{BAHAN DAN METODE}

Penelitian telah dilaksanakan di Kecamatan Sungai Rumbai Kabupaten Dharmasraya dan di Laboratorium Jurusan Tanah Fakultas Pertanian Unand.

Penelitian lapangan mencakup pengambilan sampel tanah pada lima jenis penggunaan lahan yaitu: hutan, sawit, karet, kopi, dan cokelat.. Pada setiap jenis penggunaan lahan diambil sampel tanah sedalam $20 \mathrm{~cm}$ dengan bor Belgia secara komposit sebanyak 4 ulangan. Pada setiap ulangan dilakukan pengambilan sub-sampel sebanyak 5 tempat dengan jarak 5 sampai $20 \mathrm{~m}$. Kelima sub-sampel diaduk merata menjadi satu sampel komposit. Sampel komposit ini kemudian dikeringkan, diayak dengan ayakan $2 \mathrm{~mm}$, dan selanjutnya digunakan untuk analisis.

Analisis sifat kimia tanah, hanya dibatasi terhadap nilai $\mathrm{pH}$, kandungan $\mathrm{C}$ organik, N, P, dan K tanah. Sedangkan sifat fisika tanah hanya terbatas pada nilai Berat Volume (BV) tanah.

\section{HASIL DAN PEMBAHASAN}

Nilai Berat Volume Tanah dan Beberapa Sifat Kimia Tanah

Berat volume tanah dan beberapa sifat kimia tanah pada berbagai jenis penggunaan lahan tanaman perkebunan dapat dilihat pada Tabel 1.

Berat tanah berdasarkan volume (BV) merupakan parameter sifat fisika tanah yang paling sederhana dalam menentukan kualitas suatu lahan. Dari Tabel 1 terlihat bahwa perubahan fungsi hutan ke berbagai jenis penggunaan lahan perkebunan telah menyebabkan terjadinya perubahan $\mathrm{BV}$ tanah. Rendahnya nilai BV tanah pada hutan, kebun karet, kopi, dan cokelat dicirikan oleh kandungan C-organik tanah. Sebaliknya nilai BV yang tinggi pada kebun sawit berhubungan dengan kandungan $\mathrm{C}$-organik yang rendah disamping adanya pengaruh pemadatan tanah sewaktu pembukaan lahan (Land Clearing) dan perataan lahan (Land Leveling) pada tahun 1992 dengan menggunakan alat berat. 
Tabel 1. Beberapa parameter sifat kimia dan nilai BV tanah dari berbagai jenis penggunaan lahan di Kecamatan Sungai Rumbai Kabupaten Dharmasraya,

\begin{tabular}{|c|c|c|c|c|c|}
\hline $\begin{array}{l}\text { Penggunaan } \\
\text { Lahan }\end{array}$ & $\begin{array}{c}\mathrm{BV} \\
\left(\mathrm{g} / \mathrm{cm}^{3}\right)\end{array}$ & $\begin{array}{l}\mathrm{C}- \\
\text { organik } \\
(\%)\end{array}$ & $\begin{array}{c}\text { Al-dd } \\
(\mathrm{me} / 100 \mathrm{~g} \\
)\end{array}$ & $\begin{array}{c}\text { Kejenuha } \\
\text { n Al (\%) }\end{array}$ & pH H2O \\
\hline Hutan & $0,96 b^{*}$ & $2,90 a^{*}$ & $4,22 a^{*}$ & $53,97 \mathrm{ab}$ & $4,74 \mathrm{c}$ \\
\hline Sawit & $1,37 \mathrm{a}$ & $1,86 \mathrm{~b}$ & $2,95 \mathrm{ab}$ & $40,76 \mathrm{ab}$ & $4,85 \mathrm{bc}$ \\
\hline Karet & $1,02 \mathrm{~b}$ & $2,53 \mathrm{ab}$ & $3,39 \mathrm{a}$ & $56,78 \mathrm{ab}$ & $5,11 \mathrm{~b}$ \\
\hline Kopi & $0,97 \mathrm{~b}$ & $2,19 a b$ & $2,97 \mathrm{ab}$ & $49,75 \mathrm{ab}$ & \\
\hline Cokelat & $0,97 \mathrm{~b}$ & $2,50 a b$ & $1,2 \mathrm{~b}$ & $28,45 \mathrm{ab}$ & \\
\hline
\end{tabular}

Hal ini sesuai dengan Thompson dan Troch (1978) yang menyatakan bahan organik lebih ringan dari tanah mineral. Schroeder (1983) menambahkan bahwa lapisan atas tanah yang kaya bahan organik dan gembur selalu mempunyai BV yang lebih ringan dari tanah lapisan bawah yang sama kompak dan rendah humus.

Luki (1995) menyatakan bahwa pengolahan dan pemanfaatan tanah tanpa pengembalian bahan organik akan mempercepat kehilangan bahan organik, sehingga padatan tanah akan didominasi oleh mineral-mineral tanah. Ini berarti susunan fase padat juga berubah. Perubahan fase padat tersebut juga terjadi pada perbedaan penggunaan lahan. Hal tersebut tentu akan meningkatkan nilai BV tanah. Selanjutnya Luki (1995) menyatakan bahwa perbedaan tekstur tanah berpengaruh terhadap nilai BV tanah. Pada tanah aluvial dengan tekstur pasir berlempung mempunyai $\mathrm{BV} 1,3 \mathrm{~g} / \mathrm{cm}^{3}$, tekstur lempung berpasir mempunyai BV $1,13 \mathrm{~g} / \mathrm{cm}^{3}$, sedangkan pada tekstur liat BV tanah adalah sebesar $1,04 \mathrm{~g} / \mathrm{cm}^{3}$.

\section{Kandungan C-organik}

Kandungan C-organik yang tertinggi ditemui pada hutan dan berbeda tidak nyata dengan kebun karet, cokelat, dan kopi, akan tetapi berbeda nyata dengan kebun sawit. Tingginya kandungan C-organik pada hutan berhubungan dengan pengembalian bahan organik yang berasal dari dekomposisi serasah oleh karena itu hutan dikatakan ekosistem yang stabil dan sustainable.

Tingginya kandungan C-organik pada kebun karet, cokelat, dan kopi berhubungan dengan pengembalian biomassa berupa daun, ranting dan cabang ke permukaan tanah. Namun karena jumlah populasi tanaman pada ketiga penggunaan lahan tersebut lebih sedikit dari hutan dan keragaman spesies tanaman juga lebih sedikit menyebabkan jumlah kandungan $\mathrm{C}$ organik pada kebun karet, cokelat, dan kopi masih dibawah ekosistem hutan. Rendahnya kandungan C-organik pada kebun sawit disebabkan oleh pemangkasan pelepah daun tidak dikembalikan secara merata pada lahan melainkan hanya ditumpuk pada tempattempat tertentu. Selain itu pada kebun sawit permukaan lahan selalu dibersihkan dari gulma dan tidak ada tanaman penutup tanah. Hal ini berbeda halnya dengan kebun karet dan cokelat, dimana pada lahan ini sebelumnya pernah ditanam dengan tanaman pangan seperti kedelai, padi, jagung, dan ubi kayu. Sisa-sisa panen selalu dikembalikan ke tanah sehingga mampu menjadi sumber bahan organik tanah. Pada kebun kopi sumber bahan organik hanya berasal dari bagian tanaman yang dikembalikan ke tanah karena pada lahan ini tidak pernah ditanam tanaman jenis lain selain kopi sehingga 
siklus bahan organik berlangsung secara terus menerus.

Akibat alih fungsi hutan telah menyebabkan terjadinya penurunan kandungan C-organik tanah sebesar 36\%, $13 \%, 25 \%$, dan $14 \%$ masing-masing untuk lahan yang ditanami sawit, karet, kopi, dan cokelat. Hasil ini sesuai dengan apa yang dikemukakan oleh Sombroek et al (1993) bahwa perubahan ekosistem hutan tropik ke berbagai bentuk lahan pertanian dapat menyebabkan kehilangan C-organik tanah sebesar 20 sampai 50\%.

Buckman dan Brady (1989) menyatakan bahwa level bahan organik menurun sebanyak 35\% pada tanah yang ditanami secara terus menerus dibandingkan tanah pada waktu belum dijamah dan ditanami. Padahal penurunan bahan organik sebanyak $40 \%$ adalah membahayakan dan tidak boleh dibiarkan berlangsung terus menerus.

\section{Nilai pH Tanah}

Tingginya nilai $\mathrm{pH}$ tanah pada kebun cokelat dan karet dibandingkan dengan kebun sawit, kopi dan hutan nampaknya berhubungan dengan pengelolaan lahan yang telah dilakukan. Kedua lahan tersebut telah pernah diberi input kapur $\left(\mathrm{CaCO}_{3}\right)$ sebanyak 4 ton/ha pada tahun 1984. setelah itu pada kedua lahan ini ditanam dengan tanaman pangan, seperti jagung, padi, kedelai, dan ubi kayu. Baru pada 1987 ditanami dengan tanaman karet dan cokelat. Pengapuran dapat meningkatkan $\mathrm{pH}$ tanah dan manfaatnya akan dapat dirasakan dalam waktu yang cukup lama (Hakim et al, 1987). Tisdale dan Nelson (1975) menambahkan bahwa pemberian kapur ke dalam tanah dapat dirasakan manfaatnya selama tiga atau empat tahun setelah pemberian. Berbeda halnya dengan kebun sawit yang juga diberi kapur pada tahun 1992 sebanyak $1 \mathrm{~kg} / \mathrm{batang}$ dan kopi sebanyak 4 ton/ha pada tahun 1983, namun pemberian kapur tidak disebar rata di permukaan tanah, tetapi hanya disebarkan di sekitar batang tanaman sehingga sampel tanah yang diambil untuk keperluan analisis sebenarnya sampel tanah yang belum diberi kapur. Oleh karena itu dapat dipahami nilai $\mathrm{pH}$ tanah sawit dan kopi tidak banyak berbeda dengan hutan

\section{Nilai Al-dd dan Kejenuhan Al Tanah}

Kandungan Al-dd dan kejenuhan $\mathrm{Al}$ tertinggi ditemui pada hutan, kebun karet, kopi, dan sawit. Sedangkan terendah ditemui pada kebun cokelat. Tingginya kandungan Al-dd dan kejenuhan Al sejalan dengan penurunan $\mathrm{pH}$ tanah. Dari penelitianpenelitian pada tanah mineral masam seperti di Brasil, Peru dan Puerto Rico telah diproleh keyakinan bahwa $\mathrm{Al}$ merupakan kation yang dominan pada komplek jerapan. Pada tanah-tanah masam dengan nilai $\mathrm{pH}$ kurang dari 4,5 sumber kemasaman tanah yang utama adalah ion Al yang dihidrolisis (Sanchez, 1993). Pada kebun cokelat pemberian kapur ternyata mampu menurunkan kandungan $\mathrm{Al}$ dan kejenuhan Al di dalam tanah. Menurut Hakim (1987) bahan penting dari kapur untuk menetralkan sumber kemasaman tanah adalah ion $\mathrm{CO}_{3}{ }^{-2}$ dan $\mathrm{OH}$ yang dihasilkannya. Ion $\mathrm{CO}_{3}{ }^{-2}$ mempunyai kemampuan dalam menarik ion $\mathrm{H}$ dari komplek jerapan, sedangkan untuk mengusir ion $\mathrm{Al}$ dari komplek jerapan diperlukan ion $\mathrm{OH}^{-}$.

\section{Kandungan N-total dan P Tersedia Tanah}

Pada Tabel 2 dapat dilihat kandungan N-total dan P-tersedia pada berbagai penggunaan lahan di Kecamatan Sungai Rumbai Kabupaten Dharmasraya.

Jumlah kandungan $\mathrm{N}$ total tanah pada hutan lebih tinggi dibandingkan dengan kebun kopi, karet, dan cokelat. Hal yang menarik dapat dilihat pada kebun sawit, perbedaan kandungan $\mathrm{N}$-total sangat nyata dengan hutan. Meskipun pada kebun sawit ada penambahan unsur $\mathrm{N}$ dari pupuk Urea sebanyak $1 \mathrm{~kg} / \mathrm{btg}$ sekali 6 bulan ternyata tidak mampu mempertahankan kandungan $\mathrm{N}$ dan mendekati $\mathrm{N}$ hutan. Hal ini disebabkan oleh permukaan lahan yang terbuka menyebabkan $\mathrm{N}$ tanah mudah hilang akibat drainase, erosi, penguapan, dan terangkut panen. 
Tabel 2. Kandungan $\mathrm{N}$ total dan $\mathrm{P}$ tersedia tanah dari berbagai jenis penggunaan lahan di Kabupaten Dharmasraya, Sumatera Barat.

\begin{tabular}{ccc}
\hline Penggunaan lahan & N-total $(\%)$ & P-tersedia $(\mathrm{ppm})$ \\
\hline Hutan & $0,15 \mathrm{a}^{*}$ & $8,914 \mathrm{a}^{*}$ \\
Sawit & $0,09 \mathrm{~b}$ & $8,23 \mathrm{a}$ \\
Karet & $0,11 \mathrm{ab}$ & $7,85 \mathrm{a}$ \\
Kopi & $0,15 \mathrm{a}$ & $11,40 \mathrm{a}$ \\
Cokelat & $0,10 \mathrm{ab}$ & $8,92 \mathrm{a}$ \\
\hline
\end{tabular}

* Angka-angka yang diikuti oleh huruf kecil yang sama pada kolom yang sama menunjukkan berbeda tidak nyata menurut BNJ $5 \%$.

Sebaliknya pada kebun karet dan cokelat karena sebelumnya pernah ditanam dengan berbagai jenis tanaman pangan mampu memberikan tambahan $\mathrm{N}$ kedalam tanah melalui hasil dekomposisi daun tanaman yang kaya $\mathrm{N}$ disamping sumber bahan organik utama yaitu pengembalian biomassa ke tanah. Hal yang menarik dapat dilihat pada kebun kopi dimana terjadi pengembalian bahan organik secara terus menerus karena sejak pembukaan lahan sampai sekarang tidak pernah diganti dengan tanaman lain sehingga dapat dilihat kandungan $\mathrm{N}$ kebun kopi sama hutan. Menurut Buckman dan Brady (1989) sebagian besar $\mathrm{N}$ tanah berada dalam bentuk $\mathrm{N}$ organik. Dekomposisi $\mathrm{N}$ organik merupakan proses utama dimana $\mathrm{N}$ menjadi tersedia bagi tanaman. Hakim et al (1986) menambahkan bahwa hasil dekomposisi bahan organik dapat berupa ammonium, nitrit, nitrat, dan gas hidrogen yang merupakan senyawa yang mengandung nitrogen.

Kandungan $\mathrm{P}$ tersedia tertinggi ditemui pada kebun kopi dan berbeda tidak nyata dengan kebun cokelat, hutan, sawit, dan karet. Namun berdasarkan kriteria kandungan $\mathrm{P}$ tersedia pada masing-masing lahan tersebut masih tergolong rendah. Pada kebun sawit dan cokelat penambahan $\mathrm{P}$ berasal dari pupuk TSP yang diberikan sebanyak $1 \mathrm{~kg} / \mathrm{batang}$ sekali 6 bulan. Sedangkan pada kebun karet tidak ada penambahan $\mathrm{P}$ yang berasal dari pupuk buatan. Namun rendahnya nilai $\mathrm{pH}$ tanah menyebabkan kandungan $\mathrm{P}$ tersedia menjadi rendah meskipun ada penambahan $\mathrm{P}$ dari pupuk buatan. Tingkat kemasaman tanah sangat mempengaruhi ketersediaan $\mathrm{P}$ didalam tanah. Pada $\mathrm{pH}$ kecil dari 5, $\mathrm{P}$ akan terikat secara kimia oleh $\mathrm{Al}, \mathrm{Fe}$, dan $\mathrm{Mn}$ karena pada kondisi tersebut tanah biasanya mengandung ion $\mathrm{Al}, \mathrm{Fe}$, dan $\mathrm{Mn}$ terlarut dan dapat dipertukarkan dalam jumlah yang tinggi. Makin rendah $\mathrm{pH}$ tanah maka makin besar konsentrasi $\mathrm{Al}, \mathrm{Fe}$, dan $\mathrm{Mn}$ yang dapat larut akibatnya besar pula nilai $\mathrm{P}$ yang diikat (Tan, 1995). Tingginya kandungan $P$ tersedia pada kebun kopi dibandingkan penggunaan lahan lainnya berhubungan dengan pemupukan $\mathrm{P}$ yang dilakukan serta pengembalian bahan organik ke tanah mampu meningkatkan kandungan $\mathrm{P}$ organik tanah. Menurut Sanchez (1993) keuntungan menanam tanaman berkayu yang tetap berupa terbentuknya daur hara tertutup dari pertanaman itu sendiri. Jumlah yang dipanen setiap tahun biasanya merupakan sebagian kecil dari biomassa dalam pertanaman cokelat, kelapa sawit, karet, dan banyak buah-buahan tropika. Dengan demikian kehilangan hara melalui panen tidak terlalu tinggi.

\section{KESIMPULAN}

Dari hasil penelitian dapat disimpulkan bahwa kebun karet dan cokelat merupakan sistim penggunaan lahan yang mempunyai nilai ekologi yang lebih baik dari pada kelapa sawit dan kopi. Hal tersebut terlihat dari kandungan C-organik, 
dan BV yang hampir menyamai ekosistim hutan.

\section{DAFTAR PUSTAKA}

Brady, N.C and R.R. Weil. 1999. The nature and properties of soils. $12^{\text {nd }}$ edition. Pentice Hall. New jersey.

Guggenberger, G., Christensen, B. T. and Zech, W. (1994) Land used effects on the composition of organic matter in particle size separates of soils: I. Lignin and carbohydrate signature. European journal of soil Science, 45:449-458.

, Zech, W., and Thomas, R.J. (1995) Lignin and carbohidrat alteration in particle size separates of an oxisol under tropical pastures following native Savanna. Soil Biology and Biochemistry, 27:16291638 .

Hakim, N., S.Yasin, dan Agustian. 1987. Liming, fertilizing, and using of crop residues for upland rice, maize and soybean in intercropping system on Podzolik. Interim report. FAO. Wina.
Sanchez, PA. 1993. Sifat dan pengelolaan tanah tropika. Penerbit ITB. Bandung. 51-52 hal.

Soembroek, W.G., Nachtergale, F.O., and Hebel, A. 1993. Amount, dynamics and sequestering of carbon in tropical and sub-tropical soil. Ambio. 22.

Tan, K. H. 2001. Environtmental Soil Science. Marcel Dekker, Inc. New York.

Yasin, S. 1987. Evaluasi kesuburan kimia tanah Podzolik setelah lima tahun pengusahaan tanaman pangan. Jurnal Andalas

1991. Pengapuran dan pemupukan berimbang pada podzolik Jurnal Andalas

2001a. Water and nutrient dynamic three micro-catchments Under montane forest. In ther South Ecudorian Andes. Bayreuther Bodenkunlihce Bericht Germany ISSN. 0931-6442

2001b. Change in water quality during the passage through a Tropical montane forest in South Ecuador J.Biogeo chemistry Nederland. 